\title{
Mycorrhizal association with native and invasive cordgrass Spartina spp. in San Francisco Bay, California
}

\author{
Renate Eberl* \\ Department of Evolution and Ecology, University of California Davis, Davis, California 95616, USA
}

\begin{abstract}
For the first time, hybrids of Spartina alterniflora $\times$ foliosa are reported to form mycorrhizal associations. This is important in light of the invasion dynamics within San Francisco Bay-where Spartina hybrids are invading tidal habitats and causing functional changes in the ecosystem. Mycorrhizal associations can positively influence biomass production in invasive Spartina and may contribute to increased invasion success. Of the Spartina hybrids investigated, $83 \%$ were mycorrhizal. During hybridization, the ability to be mycorrhizal may be contributed by the native $S$. foliosa, also found to be mycorrhizal, whereas the introduced $S$. alterniflora is non-mycorrhizal in its native habitat. Seedlings of Spartina hybrids inoculated with a commercial mycorrhizal mix showed greater above-ground growth and total biomass compared to control plants in the greenhouse. Mycorrhizal associations have the po-tential to influence the invasion trajectory of hybrid Spartina in San Francisco Bay, but additional research is needed.
\end{abstract}

KEY WORDS: Mycorrhizae · Spartina spp. $\cdot$ Hybrid Salt marsh $\cdot$ Mycorrhizal inoculation · Invasion

Resale or republication not permitted without written consent of the publisher

\section{INTRODUCTION}

Facilitative interactions between species can lead to increased invasion success (Richardson et al. 2000, Ricciardi 2001, Grosholz 2005), with symbiotic microorganisms often playing important roles in shaping invasion dynamics (Clay 2001, Pringle et al. 2009). Fungi are among the most important symbionts of animal and plant hosts and have been associated

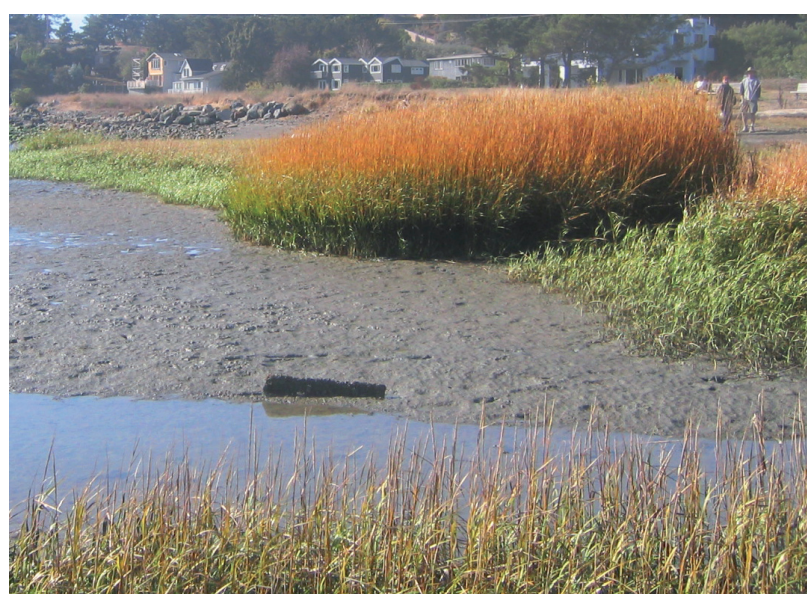

Invasive clones of hybrid Spartina alterniflora $\times$ foliosa in San Francisco Bay are causing changes in the functioning of the ecosystem. Mycorrhizal associations with hybrid Spartina are possibly affecting invasion dynamics.

Photo: Christina Sloop

with plants in mycorrhizal associations since the first colonization of land (Cairney 2000, Heckman et al. 2001). Mycorrhizal symbioses are present in $80 \%$ of surveyed plant species (Cairney 2000, Wang \& Qiu 2006). Mycorrhizae enhance nutrition and increase the fitness of individual plants, and they can shape the structure and dynamics of plant populations and communities in a variety of environments (Isaac 1992, van der Heijden \& Sanders 2002, Smith \& Read 2008).

The mutualistic basis for mycorrhizal associations is largely due to a bidirectional transfer of nutrients: carbon from plant to fungus, and mineral nutrients (mostly phosphorus and nitrogen) from fungus to host plant (van der Heijden \& Sanders 2002). The 
location of the fungal symbiont in the plant's root, and its hyphal connections with the soil, ensure that it influences the plant's absorption of nutrients from the soil while obtaining organic carbon from the host plant (Smith \& Read 2008). In addition to the survival and productivity of the host plant (Morton et al. 2004, Deacon 2006), mycorrhizal colonization can also influence plant traits such as clonal morphology, foliar quality, and fitness (Gehring \& Whitman 2002, Kernaghan 2005). Moreover, mycorrhizal associations can improve water absorption or provide defense against pathogenic microorganisms and herbivores (Smith \& Read 2008). Mycorrhizal fungi also play important roles in the succession and maintenance of plant communities (Brundrett 1991, Allen et al. 1995).

The fungi that form arbuscular mycorrhizal (AM) associations are members of the Glomeromycota, which are considered to be obligate mycorrhizal symbionts and which form hyphae that lack cross walls. AM fungi form specialized structures, called arbuscules, in plant root cells, and these structures are the sites of the transfer of nutrients between fungus and plant (Smith \& Read 2008). A global analysis of AM fungal communities suggests high variability in taxon richness and species composition between different ecosystems (Opik et al. 2006). While it is thought that water-logged soils reduce mycorrhizal growth (Khan \& Belik 1995), some aquatic plants have been reported to show AM infection (Cooke \& Lefor 1998, Hildebrandt et al. 2001, Burke et al. 2003, Daleo et al. 2008). Evidence exists that mycorrhizae may be important components of salt marsh ecosystems (Rozema et al. 1986, Vanduin et al. 1990, Hoefnagels et al. 1993, Cooke \& Lefor 1998). For example, the presence of AM fungi in salt marsh plants may increase competitive ability through increased phosphorus uptake, and through increased nitrogen acquisition as a result of reduced phosphorus limitation of root-associated diazotrophs (Hildebrandt et al. 2001).

Salt marshes are among the most productive and frequently invaded ecosystems on earth (Grosholz 2002). The halophyte cordgrass Spartina spp. is a highly productive primary producer in salt marshes. Spartina foliosa is the only native Spartina species on the North American Pacific coast (Moberly 1956), $S$. alterniflora, $S$. patens and $S$. densiflora have been introduced there accidentally or deliberately by humans (Ayres et al. 2004). The introduced S. alterniflora hybridized with the native $S$. foliosa in San Francisco Bay, and these $S$. alterniflora $\times S$. foliosa hybrids (henceforward 'Spartina hybrids' or 'hybrid Spartina') have spread rapidly across the Bay (Daehler \& Strong 1997, Ayres et al. 2004). Spartina foliosa is restricted to elevations above mean sea level (MSL), whereas hybrids invade mud flats below MSL as well as Sarcocornia meadows (Ayres et al. 2004). Spartina hybrids have greater above-ground biomass compared to native $S$. foliosa but differences among hybrids have been observed and have been partially explained by their percentage of hybridity (Ayres et al. 2004). I posit that some of these differences in biomass and height may be due to microbial associations, particularly associations with AM fungi.

Previous studies have found no (Hoefnagels et al. 1993) or extremely low (McHugh \& Dighton 2004) mycorrhizal infections of Spartina alterniflora in its native habitat, but several other species of Spartina have been reported as mycorrhizal (Brown 1994, Burke et al. 2002, 2003). The occurrence and importance of AM fungi in native $S$. foliosa, and in introduced $S$. alterniflora and $S$. densiflora, as well as in invasive hybrids, has not been investigated. I present a survey of colonization by AM fungi of salt marsh plants in San Francisco Bay, California, with emphasis on different species of the cordgrass Spartina spp. (the native $S$. foliosa, the introduced species $S$. alterniflora and $S$. densiflora) as well as Spartina hybrids. Field sampling that spanned the range of tidal extent of each collected species at a site was conducted at Cogswell Marsh and Richardson Bay Park. In a greenhouse experiment seedlings were inoculated with a commercial mycorrhizal mix to determine the effect of mycorrhizal inoculation on plant biomass. The goals of this study were (1) to determine the prevalence and extent of mycorrhizal infection in both native and introduced Spartina spp. in San Francisco Bay, (2) to compare mycorrhizal infection rates in Spartina spp. with those in other estuarine plants, and (3) to determine, via a greenhouse experiment, whether inoculation with AM fungi influences Spartina growth and potential competitive ability.

\section{MATERIALS AND METHODS}

\section{Mycorrhizal colonization of Spartina spp. in San Francisco Bay}

Two sites were chosen in San Francisco Bay, California, where native, introduced, and hybrid Spartina spp. grow close together: Cogswell Marsh (37 33' $20^{\prime \prime}$ N, $122^{\circ} 07^{\prime} 27^{\prime \prime}$ W) and Richardson Bay Park near Blackie's Pasture ( $\left.37^{\circ} 53^{\prime} 24^{\prime \prime} \mathrm{N}, 122^{\circ} 27^{\prime} 59^{\prime \prime} \mathrm{W}\right)$. Plants were identified on the basis of previous molecular genetic studies of hybridization in Spartina spp. 
(Ayres et al. 2004, Ayres unpubl.) and on morphological characteristics for field identification (Invasive Spartina Project http://www.spartina.org/species.htm). In addition to cordgrasses, the following native estuarine plants were sampled as a comparison of mycorrhizal infection rates: Sarcocornia pacifica, Jaumea carnosa, Distichlis spicata and Grindelia sp. With the exception of $S$. pacifica, these species grow in tidal elevation above the Spartina spp. invasion zone (Grewell et al. 2007). Root samples spanning the range of elevation of each species at that site were collected in the summer of 2006. A total of 5 or 6 replicate root samples of each species was collected at each site, except for Spartina densiflora $(\mathrm{n}=3)$ where only a few clones were available. All samples were obtained by digging up the roots of single plants or portions of clones (Spartina spp.) to a depth of $\sim 20 \mathrm{~cm}$. When several species of plants were growing within a small area, care was taken to eliminate roots of non-target species within the sample. Samples were brought back to the laboratory where roots of individual plants were rinsed in tap water and the complete root sample was cut into $2.5 \mathrm{~cm}$ pieces. Two subsamples (each $\sim 75$ root pieces) were taken per plant and placed in separate tissue cassettes (Omnisette, Fisher Scientific) for further processing. Roots were cleared in $10 \%$ potassium hydroxide $(\mathrm{KOH})$ solution for $20 \mathrm{~min}$ and stained with trypan blue in lactoglycerol for 30 min (Kormanik \& McGraw 1982). Stained roots were mounted in $50 \%$ polyvinyl-lactoglycerol (PVLG) on microscope slides, and colonization was estimated using the cross-hair intersection method (McGonigle et al. 1990), with a minimum target of 50 observations per slide. For each slide it was determined whether or not mycorrhizae were found, and the percentage of mycorrhizal samples $(\%+\mathrm{Myc})$ out of the total number of slides was determined. The percentage mycorrhizal infection of root length $\left(\% \mathrm{RL}_{\mathrm{Myc}}\right)$ was determined as the percentage of AM fungal structures observed divided by the total number of root sections observed.

\section{Greenhouse experiment}

Seeds were collected in November 2006, from multiple clones of hybrid Spartina at Richardson Bay Park and multiple clones of native $S$. foliosa at China Camp State Park $\left(38^{\circ} 00^{\prime} 12^{\prime \prime}\right.$ N, $\left.122^{\circ} 28^{\prime} 03^{\prime \prime}\right)$. Seeds were separated from stems, sorted in the laboratory for maturity, and stored at $4^{\circ} \mathrm{C}$. Seeds were rehydrated with $1 \%$ artificial seawater at $4{ }^{\circ} \mathrm{C}$ for $4 \mathrm{wk}$, and the water was changed every week to minimize microbial contamination (Daehler \& Strong 1997). Seeds were then surface-sterilized in a $10 \%$ bleach solution for $5 \mathrm{~min}$ to kill surface fungi, and rinsed in distilled water. A subsample of 10 seeds was placed in individual Petri dishes, with distilled water covering the seeds ( $\mathrm{n}=100$ seeds per species) at room temperature and exposed to ambient light to induce germination. Seeds were checked every 2 to $3 \mathrm{~d}$ to detect the start of germination, and water was changed when cloudy. The germination rate was $\sim 50 \%$ for hybrids, but none of the $S$. foliosa seeds germinated. Once the hybrid seedlings had reached a length of $\sim 2 \mathrm{~cm}$, individual seedlings $(\mathrm{n}=50)$ were transplanted to $600 \mathrm{ml}$ pots and kept in the greenhouse with overhead watering for 5 min every $6 \mathrm{~h}$. After $3 \mathrm{wk}$, seedlings that had grown well (showed no yellow or brown on tiller) were paired according to similarity in plant height and randomly assigned to treatments (mycorrhizal $(+\mathrm{M})$ or no mycorrhizal $(-\mathrm{M})$ inoculate, $\mathrm{n}=20$ per treatment). All seedlings were replanted in individual pots in a sterile potting mix of 7 parts Yolo County loam and 3 parts potting mix. The bottom one-third of each $600 \mathrm{ml}$ pot was filled with soil mixture. The middle third was filled with either a 1:1 mixture of sterile soil and mycorrhizal inoculate $(+\mathrm{M})$ or soil mix $(-\mathrm{M})$; the top third of all pots was filled with sterile soil mix. The mycorrhizal fungal inoculum used-MycoApply Endo (Mycorrhizal Applications Inc.) — contained a mixture of the following 4 AM fungal species: Glomus intraradices, G. aggregatum, G. mosseae and G. etunicatum. Plants were kept in the greenhouse at the University of California Bodega Marine Laboratory (Bodega Bay, CA) under ambient conditions for $12 \mathrm{wk}$. Plants were measured for height of the tallest tiller and the number of tillers every 2 to $4 \mathrm{wk}$. At the end of the experiment, soil was carefully rinsed off all roots, and the plants were dried at $60^{\circ} \mathrm{C}$ for $48 \mathrm{~h}$; dry weight was determined for root and shoot biomass. Twenty treatment pairs were analyzed with paired 2-tailed $t$-tests to test differences among treatments $(+\mathrm{M}$ vs. $-\mathrm{M})$.

\section{RESULTS}

\section{Mycorrhizal colonization of Spartina spp. in San Francisco Bay}

Native Spartina foliosa, introduced S. alterniflora and $S$. densiflora, and hybrid Spartina were all colonized by AM fungi (Table 1). S. alterniflora, which previous studies have shown to be non-mycorrhizal, contained mycorrhizae in only $30 \%$ of the samples in- 
Table 1. Mycorrhizal association of native (N) and introduced (I) Spartina spp. and other saltmarsh plants reported as the percentage of samples with mycorrhizal hyphae $(\%+\mathrm{Myc})$ and the average percentage of root length with mycorrhizal infection ( $\left.\% \mathrm{RL}_{\mathrm{Myc}} \pm \mathrm{SE}\right)$ per sample. $\mathrm{n}=$ number of replicates per sample

\begin{tabular}{|c|c|c|c|c|}
\hline Species & $\begin{array}{l}\text { Native/ } \\
\text { introduced }\end{array}$ & $\%+\mathrm{Myc}$ & $\begin{array}{c}\% \mathrm{RL}_{\mathrm{Myc}} \\
\pm \mathrm{SE}\end{array}$ & $\mathrm{n}$ \\
\hline Spartina foliosa & $\mathrm{N}$ & 70 & $8.9 \pm 3.6$ & 10 \\
\hline Spartina alterniflora & I & 30 & $1.0 \pm 0.5$ & 10 \\
\hline Spartina densiflora & I & 100 & $5.9 \pm 1.7$ & 3 \\
\hline Spartina hybrids & I & 83 & $4.7 \pm 1.1$ & 12 \\
\hline Sarcocornia pacifica & $\mathrm{N}$ & 100 & $17.4 \pm 3.4$ & 10 \\
\hline Distichlis spicata & $\mathrm{N}$ & 100 & $14.2 \pm 3.0$ & 10 \\
\hline Jaumea carnosa & $\mathrm{N}$ & 100 & $19.4 \pm 5.5$ & 10 \\
\hline Grindelia sp. & $\mathrm{N}$ & 100 & $14.3 \pm 5.0$ & 10 \\
\hline
\end{tabular}

vestigated, whereas $70 \%$ of $S$. foliosa and $83 \%$ of hybrids showed mycorrhizal infections. The 3 samples of S. densiflora were all mycorrhizal, as were all samples of Sarcocornia pacifica, Jaumea carnosa, Grindelia sp. and Distichlis spicata. The average percentage of root length with mycorrhizal infection (\%RL $\mathrm{RL}_{\mathrm{Myc}}$ ) per sample was not significantly different between the 2 sites (Wilcoxon Rank Sums p > 0.05 for all species comparisons) and data from different sites were combined. Mycorrhizal infection rates in all species of Spartina were $<10 \% \mathrm{RL}_{\mathrm{Myc}}$ and $\sim 10$-fold lower than infection rates in S. pacifica, J. carnosa, Grindelia sp. and D. spi- cata (Table 1) which tend to grow at higher elevations than Spartina spp., with the exception of S. pacifica.

\section{Greenhouse experiment}

Total and above-ground biomass were greater in hybrids grown with mycorrhizal inoculate in the greenhouse. Plants with this treatment also grew taller (Fig. 1). The mean \pm SE total dry weight biomass for Spartina spp. grown in the greenhouse with mycorrhizal inoculate $(+\mathrm{M})$ was $2802 \pm 221 \mathrm{mg}$ as compared to a total biomass of $2292 \pm 204 \mathrm{mg}$ in the treatment without inoculate $(-\mathrm{M})$, with a highly significant difference between groups (paired $t=3.01, \mathrm{p}<0.01$, $\mathrm{df}=19$ ). Spartina spp. $+\mathrm{M}$ showed higher aboveground but not below-ground biomass as compared to Spartina spp. $-\mathrm{M}$ (paired $t$-tests: shoot biomass $t=$ $3.86 \mathrm{p}<0.01$, root biomass $t=1.16, \mathrm{p}=0.26$ ) (Fig. 1). Plants grown with mycorrhizas grew on average taller (mean $\pm \mathrm{SE}_{\text {; }} 518.1 \pm 19.3 \mathrm{~mm}$ ) than those without mycorrhizae $(457.7 \pm 15.4 \mathrm{~mm})$ as measured by the height of the tallest tiller (paired $t=2.45, \mathrm{p}<0.05$ ), but no difference in the number of tillers per plant could be detected (paired $t=0.64, \mathrm{p}=0.42$ ). Plants grown with mycorrhizal inoculant had a significantly lower rootto-shoot ratio $\left(\right.$ mean $\pm \mathrm{SE}_{i}+\mathrm{M} 0.661 \pm 0.12,-\mathrm{M} 0.806 \pm$ $0.24, t=-2.43, \mathrm{p}<0.05$ ) (Fig. 1).
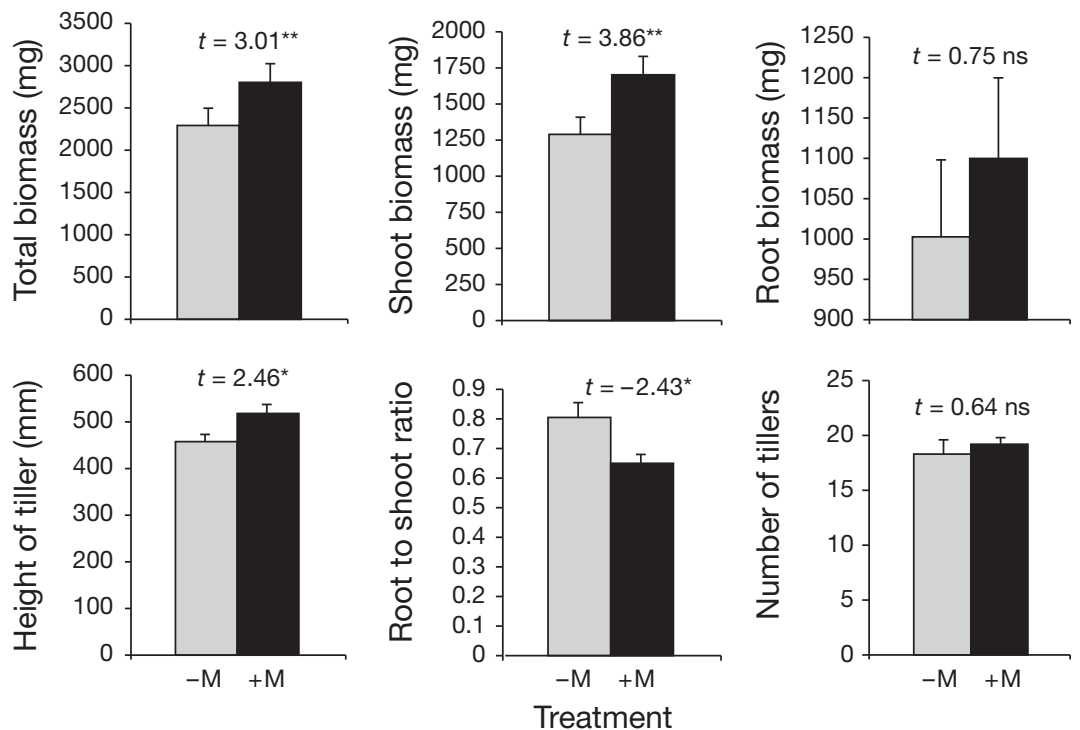

Fig. 1. Results of the greenhouse experiment comparing Spartina hybrids grown without ( $-\mathrm{M}$, grey bars) and with (+M, black bars) commercial mycorrhizal inoculate $(\mathrm{M})$. Bars depict mean values for treatments; significance of differences between treatments was determined with paired 2-tailed $t$-tests; ${ }^{*} \mathrm{p}<0.05,{ }^{* *} \mathrm{p}<0.01, \mathrm{~ns}=$ not significant, $\mathrm{df}=19$

\section{DISCUSSION}

Swarms of Spartina alterniflora $\times$ foliosa hybrids are invading both high and low marshes, are displacing native $S$. foliosa, and are causing changes in the functioning of the ecosystem by altering water flow, light penetration and sediment deposition within marshes (Levin et al. 2006, Neira et al. 2006). For the first time, Spartina hybrids are shown to form mycorrhizal associations in this highly invaded habitat. Mycorrhizae have previously been reported only from $S$. cynosuroides, $S$. densiflora, $S$. gracilis, $S$. patens and $S$. pectinata. This is the first report of mycorrhizal infection of S. foliosa and of Spartina hybrids. In introduced Spartina spp., hybridization may cause an increased ability to associate with AM fungi. Both native $S$. foliosa and hybrid 
Spartina showed a greater percentage of mycorrhizal infections than did introduced $S$. alterniflora.

Previous reports indicate that $S$. alterniflora lacks AM fungi in its native habitat on the Atlantic coast (reviewed in Brown 1994) and failed to become infected after 2 mo of growth with AM fungal inocula in the greenhouse (McHugh \& Dighton 2004). I identified plants in the field as pure $S$. alterniflora based on morphological characteristics and previous molecular work with random amplified polymorphic DNA (RAPD) markers (Ayres et al. 2004). Differences in the degree of hybridity between samples of Spartina hybrids from San Francisco Bay have been shown with molecular markers (RAPD: Ayres et al. 2004, and microsatellite: Sloop et al. 2011). It is possible that some of the samples identified as pure $S$. alterniflora in this study may be cryptic hybrids with a low percentage of hybridity that could not be detected with RAPD markers.

It is generally difficult to compare infection rates directly among existing studies as different methods are often used (Gange et al. 1999). In the present study multiple species of Spartina are compared, which allows for a relative comparison of infection rates within the study. It appears that the ability to form mycorrhizae may have been conferred on the invasive hybrid by the native $S$. foliosa.

This study found greater colonization by mycorrhizae of plant species growing in higher elevation zones of marshes as compared to the lower zone occupied primarily by Spartina spp. Pugh (1961) also reported a higher number of fungal isolations from upland zones compared to bare mud flats on the Atlantic coast. He suggested that fungi were probably limited by the reducing conditions present in $S$. alterniflora sites. Cooke \& Lefor (1990) hypothesized that the absence of mycorrhizae in S. alterniflora was due to harsh edaphic conditions common to its flooded environment. This notion was challenged by Hoefnagels et al. (1993) who investigated the mycorrhizal status of 5 salt marsh species-including $S$. alterniflora, S. patens, S. cynosuroides, Distichlis spicata and Juncus roemerianus-collected from 8 different North Carolina salt marshes. All species except $S$. alterniflora were mycorrhizal. These authors concluded that $S$. alterniflora is probably resistant to infection because $S$. patens grown in the same soil mixtures became mycorrhizal. Except for the presence of AM hyphae in S. alterniflora, the results of the present study match Hoefnagels et al. (1993) wherever equivalent species were investigated.

Glomus spp. appear to be the most commonly en- countered AM fungi in salt marsh soils (Sengupta \& Chaudhuri 1990, Carvalho et al. 2004, Wilde et al. 2009). A large portion of mycorrhizal hyphae in our samples belonged to this genus, but we also observed mycorrhizal hyphae with much smaller diameters that most likely belonged to the genus Scutellospora (A. Bennet, Scottish Crop Research institute, pers. comm.), in both $S$. foliosa and hybrids. Detailed analysis of AM diversity was beyond the scope of this study, but future work should make use of morphological characteristics of fungi and available molecular markers (Raab et al. 2005) to determine differences in mycorrhizae associated with native and hybrid Spartina.

Hybrid Spartina grown with mycorrhizal inoculant had a significantly larger total as well as aboveground biomass compared to non-inoculated plants, whereas no significant difference in root biomass was apparent. Mycorrhizal plants also grew taller. The increase in above-ground biomass and the increased height of tillers could represent a fitness advantage to the plant, as it allows it to keep more shoots above tidal inundation and allows for the colonization of lower elevation sites, while maintaining sufficient above-ground shoots for photosynthesis at all times. A reduced root-to-shoot ratio was observed in plants grown with AM fungi. Increased nutrient absorption due to the symbiosis could have reduced the requirement for large root biomass, freeing resources that can be invested in above-ground production (Smith \& Reed 2008). Plants may invest fewer resources in root growth as AM fungi perform the work of additional roots (McHugh \& Dighton 2004).

In a previous field experiment, the outcome of competition between Spartina alterniflora and S. densiflora was affected by AM infection and depended on nutrient conditions (Daleo et al. 2008). In low nutrient conditions, mycorrhizae conferred a competitive advantage on $S$. densiflora. Different nutrient conditions were not explicitly investigated in the present study, but should be investigated in future research. Phosphorus levels in the present study were relatively high due to the fertilization regime used. For both $S$. alterniflora and $S$. cynosuroides, McHugh \& Dighton (2004) showed a greater effect of nutrients on plant biomass in inoculated plants, compared with uninoculated plants, when growth occurs in low-phosphorus conditions but not in highphosphorus conditions.

The results of this study are a first step in demonstrating the potential effect of mycorrhizae on hybrid Spartina invasion. The results from the greenhouse study should be repeated by comparative inoculation 
experiments under more natural conditions (e.g. inoculation with local mycorrhizae, use of local soils and frequent inundation). Future work should also include field manipulation of mycorrhizal associations in Spartina spp. via the application of fungicides. This work could be combined with eradication efforts currently under way with the Invasive Spartina Project. This study suggests that a cautious attitude be adopted in restoration efforts targeting native species and using mycorrhizal fungal inoculate to help in the establishment of plants, because, in salt marsh ecosystems, inoculation with AM fungi will not necessarily provide an advantage to native species over invaders. While this study does not conclusively demonstrate that mycorrhizae are facilitating the invasion of tidal lands by Spartina hybrids, and further research is required, mycorrhizal associations have the potential to influence the invasion trajectory of Spartina hybrids in San Francisco Bay.

Acknowledgements. I am grateful to A. Bennett for sharing her knowledge of mycorrhizae and for technical training. I am thankful to D. Ayres and D. S. Strong for help with finding optimal field sites, and with identification of Spartina hybrids. Thanks to C. Bledsoe for microscope use, to P. Riley and J. Sones for help in the greenhouse. I am grateful to the Bodega Marine Laboratory for providing greenhouse space. Thanks to A. Bennet, D. Ayres, L. Feinstein, T. Grosholz for suggestions to improve this manuscript. Funding for this research was provided through NSF grant DGE 0841297 to S. L. Williams, an Invasion IGERT short-term fellowship training grant CPBIGRT - GSRXE, and a Bodega Marine Laboratory travel grant. This publication is a contribution of the Bodega Marine Laboratory, University of California at Davis.

\section{LITERATURE CITED}

Allen EB, Allen MF, Helm DJ and others (1995) Patterns and regulation of mycorrhizal plant and fungal diversity. Plant Soil 170:47-62

Ayres DR, Smith DL, Zaremba K and others (2004) Spread of exotic cordgrasses and hybrids (Spartina sp.) in the tidal marshes of San Francisco Bay, California, USA. Biol Invasions 6:221-231

Brown AM (1994) The natural history of vesicular-arbuscular mycorrhizae in a California tidal salt marsh. $\mathrm{PhD}$ thesis, University of California Davis

Brundrett M (1991) Mycorrhizas in natural ecosystems. Adv Ecol Res 21:171-313

> Burke DJ, Hamerlynck EP, Hahn D (2002) Interactions among plant species and microorganisms in salt marsh sediments. Appl Environ Microbiol 68:1157-1164

Burke DJ, Hamerlynck EP, Hahn D (2003) Interactions between the salt marsh grass Spartina patens, arbuscular mycorrhizal fungi and sediment bacteria during the growing season. Soil Biol Biochem 35:501-511

> Cairney JWG (2000) Evolution of mycorrhiza systems. Naturwissenschaften 87:467-475

Carvalho LM, Correia PM, Martins-Loucao MA (2004) Arbus- cular mycorrhizal fungal propagules in a salt marsh. Mycorrhiza 14:165-170

Clay K (2001) Symbiosis and the regulation of communities. Am Zool 41:810-824

Cooke JC, Lefor MW (1990) Comparison of vesicular-arbuscular mycorrhizae in plants from disturbed and adjacent undisturbed regions of a coastal salt marsh in Clinton, Connecticut, USA. Environ Manag 14:131-137

> Cooke JC, Lefor MW (1998) The mycorrhizal status of selected plant species from Connecticut wetlands and transition zones. Restor Ecol 6:214-222

> Daehler C, Strong DR (1997) Hybridization between introduced smooth cordgrass (Spartina alterniflora; Poaceae) and native California cordgrass ( $S$. foliosa) in San Francisco Bay, California, USA. Am J Bot 84:607-611

Daleo P, Alberti J, Canepuccia A and others (2008) Mycorrhizal fungi determine salt-marsh plant zonation depending on nutrient supply. J Ecol 96:431-437

Deacon J (2006) Fungal biology. Blackwell, Oxford

> Gange AC, Bower E, Stagg PG and others (1999) A comparison of visualization techniques for recording arbuscular mycorrhizal colonization. New Phytol 142:123-132

Gehring CA, Whitman TG (2002) Mycorrhizae-herbivore interactions: population and communtiy consequences. In: Van der Heijden MGA, Sanders IA (eds) Mycorrhizal ecology. Springer, Berlin, p 295-320

Grewell BJ, Callaway JC, Ferren WR (2007) Estuarine wetlands. In: Barbour MG, Keeler-Wolf T, Schoenherr AA (eds) Terrestrial vegetation of California. University of California Press, Berkeley, CA, p 124-155

Grosholz E (2002) Ecological and evolutionary consequences of coastal invasions. Trends Ecol Evol 17:22-27

> Grosholz ED (2005) Recent biological invasion may hasten invasional meltdown by accelerating historical introductions. Proc Natl Acad Sci USA 102:1088-1091

Heckman DS, Geiser DM, Eidell BR and others (2001) Molecular evidence for the early colonization of land by fungi and plants. Science 293:1129-1133

Hildebrandt U, Janetta K, Ouziad F and others (2001) Arbuscular mycorrhizal colonization of halophytes in Central European salt marshes. Mycorrhiza 10:175-183

> Hoefnagels MH, Broome SW, Shafer SR (1993) Vesiculararbuscular mycorrhizae in salt marshes in NorthCarolina. Estuaries 16:851-858

Isaac S (1992) Fungal-plant interactions. Chapman \& Hall, London

Kernaghan G (2005) Mycorrhizal diversity: Cause and effect? Pedobiologia (Jena) 49:511-520

Khan AG, Belik M (1995) Occurrence and ecological significance of mycorrhizal symbiosis in aquatic plants. In: Varma A, Hock B (eds) Mycorrhiza: structure, function, molecular biology and biotechnology. Springer, Berlin, p 627-666

Kormanik PP, McGraw AC (1982) Quantification of vesicular-arbuscular mycorrhizas in plant roots. In: Schenck NC (ed) Methods and principles of mycorrhizal research. The American Phytopathological Society, St. Paul, MN, p 37-45

Levin LA, Neira C, Grosholz ED (2006) Invasive cordgrass modifies wetland trophic function. Ecology 87:419-432

> McGonigle TP, Miller MH, Evans DG and others (1990) A new method which gives an objective measure of colonization of roots by vesicular arbuscular mycorrhizal fungi. New Phytol 115:495-501

McHugh JM, Dighton J (2004) Influence of mycorrhizal 
inoculation, inundation period, salinity, and phosphorus availability on the growth of two salt marsh grasses, Spartina alterniflora Lois. and Spartina cynosuroides (L.) Roth., in nursery systems. Restor Ecol 12:533-545

Moberly DG (1956) Taxonomy and distribution of the genus Spartina. Iowa State Coll J Sci 30:471-574

Morton JB, Koske RE, Stuermer SL and others (2004) Mutualistic arbuscular endomycorrhizal fungi. In: Mueller GM, Bills GF, Foster MS (eds) Biodiversity of fungi: inventory and monitoring methods. Elsevier, Amsterdam, p 317-336

Neira C, Grosholz ED, Levin LA and others (2006) Mechanisms generating modification of benthos following tidal flat invasion by a Spartina hybrid. Ecol Appl 16: 1391-1404

Opik M, Moora M, Liira J and others (2006) Composition of root-colonizing arbuscular mycorrhizal fungal communities in different ecosystems around the globe. J Ecol 94: 778-790

Pringle A, Bever JD, Gardes M, Parrent JL, Rillig MC, Klironomos JN (2009) Mycorrhizal symbioses and plant invasions. Annu Rev Ecol Evol Syst 40:699-715

Pugh GJF (1961) Fungal colonization of a developing salt marsh. Nature 190:1032-1033

Raab PA, Brennwald A, Redecker D (2005) Mitochondrial large ribosomal subunit sequences are homogeneous within isolates of Glomus (arbuscular mycorrhizal fungi, Glomeromycota). Mycol Res 109:1315-1322

Ricciardi A (2001) Facilitative interactions among aquatic invaders: Is an 'invasional meltdown' occurring in the

Editorial responsibility: Hans Heinrich Janssen, Oldendorf/Luhe, Germany
Great Lakes? Can J Fish Aquat Sci 58:2513-2525

Richardson DM, Allsopp N, D'Antonio CM and others (2000) Plant invasions-the role of mutualisms. Biol Rev Camb Philos Soc 75:65-93

Rozema J, Arp W, Vandiggelen J and others (1986) Occurence and ecological significance of vesicular arbuscular mycorrhiza in the salt-marsh environment. Acta Bot Neerl 35:457-467

> Sengupta A, Chaudhuri S (1990) Vesicular arbuscular mycorrhizae (VAM) in pioneer salt-marsh plants of the Ganges River Delta in West Bengal (India). Plant Soil 122:111-113

Sloop CM, Ayres DR, Strong DR (2011) Spatial and temporal genetic structure in a hybrid cordgrass invasion. Heredity 106:547-556

Smith SE, Read DJ (2008) Mycorrhizal symbiosis, 3rd edn. Academic Press, London

van der Heijden MGA, Sanders IA (2002) Mycorrhizal ecology. Springer, Berlin

> Vanduin WE, Rozema J, Ernst WHO (1990) Seasonal and spatial variation in the occurence of vesicular-arbuscular (VA) mycorrhiza in salt-marsh plants. Agric Ecosyst Environ 29:107-110

Wang B, Qiu YL (2006) Phylogenetic distribution and evolution of mycorrhizas in land plants. Mycorrhiza 16: 299-363

Wilde P, Manal A, Stodden M and others (2009) Biodiversity of arbuscular mycorrhizal fungi in roots and soils of two salt marshes. Environ Microbiol 11:1548-1561

Submitted: June 23, 2011; Accepted: September 15, 2011 Proofs received from author(s): November 3, 2011 